\title{
Un nou factor al evoluției ${ }^{\dagger}$
}

\author{
James Mark Baldwin
}

În citteva scrieri recente am dezvoltat, din diferite perspective, cîteva considerații prin care am vrut să scot la iveală o anumită influență în cadrul evoluției organice, pe care m-am încumetat să o numesc „un nou factor". Ofer aici o listă de referințe ${ }^{1}$ la aceste scrieri-la care voi face trimitere pe parcursul articolului de faţă. Obiectul acestuia este de a oferi un rezumat al perspectivei asupra procesului de evoluție, articulate în aceste scrieri.

Chestiunile implicate într-o teorie a evoluției organice pot fi adunate sub trei mari titluri: Ontogenie, Filogenie, Ereditate. Tema generală, factorul pe care îmi propun să îl evidențiez, este operațională, în primă instanță, în domeniul Ontogeniei. În consecință, voi vorbi mai întîi despre chestiunea Ontogeniei; apoi-în măsura în care o cere tema în discuţie-, despre cea a Filogeniei; apoi, despre cea a Eredității-ținînd seamă de aceeași constrîngere-; iar în cele din urmă voi oferi unele definiții și concluzii.

\section{I.}

Ontogenie: 'selecție organică (a se vedea ref. b., cap. VII).-Seriile de fapte care privesc cercetarea din cadrul acestui domeniu sînt cele ale evoluției ființei individuale. Din punctul de vedere al funcţiilor pe care le execută un organism în decursul vieții sale, se pot distinge două tipuri de fapte. În primul rînd, dezvoltarea impulsului eredităţii, desfăşurarea eredității sale în forme şi funcții ce caracterizează felul acelui organism, dimpreună cu variațiile congenitale ce caracterizează individul concret—variațiile filogenetice, care-i sînt constitutive. În al doilea rînd, seriile de funcții, procese etc., pe care învață singur să le efectueze, în decursul vieții. Luate împreună, toate acestea din urmă-modificările speciale pe care le dobîndește un organism pe parcursul ontogeniei-au fost numite "trăsături dobîndite”, iar noi putem folosi această expresie sau putem adopta una recent sugerată de către Osborn $^{2}$, „variații ontogenice” (cu excepția faptului că aș prefera forma „variații ontogenetice”)—aceasta, dacă vom considera potrivit termenul „variaţii".

Presupunînd că există, în prima fază, astfel de funcții noi sau modificate şi, apoi, astfel de „trăsături dobîndite”, apărute din funcțiile noi ca urmare a manifestării legii „,̂nnrebuințării și neîntrebuințării”, următoarea noastră întrebare se referă la acestea. Iar întrebarea este: Cum ajunge un organism să se modifice de-a lungul existenței sale?

Încercînd să răspundem la această întrebare aflăm că trebuie făcută distincția între trei tipuri de factori ontogenici, fiecare dintre ei acționînd în direcția producerii de modificări, adaptări sau variații ontogene-

${ }^{\dagger}$ Publicat în “The American Naturalist,” vol. XXX, nr. 354, iunie 1896, p. 441-451, CrossRef, și vol. XXX, nr. 355, iulie 1896, p. 536-553, CrossRef.

${ }^{1}$ Referințe:

(a). Imitation: a Chapter in the Natural History of Consciousness, în „Mind”, III, nr. 9, ian., 1894, Londra. În acest articol și în trimiterea următoare se găsesc citări din texte anterioare.

(b). Mental Development in the Child and the Race, ed. 1, apr., 1895; ed. a 2-a, oct., 1895; Macmillan \& Co. Articolul de față adaugă un capitol (cap. XVII), prezent în edițiile germană și franceză, și care urmează a fi încorporat în cea de-a treia ediție în limba engleză.

(c). Consciousness and Evolution, în „Science”, 23 aug., 1895; retipărit în „The American Naturalist”, apr., 1896.

(d). Heredity and Instinct (I), în „Science”, 20 mart., 1896. Prezentare în ședința din 31 ian., 1896, a Academiei de Științe din New York.

(e). Heredity and Instinct (II), în „Science”, 10 apr., 1986.

(f). Physical and Social Heredity, în „The American Naturalist”, mai, 1896.

(g). Consciousness and Evolution, în „Psychological Review”, mai, 1896. Discuție din 28 dec., 1895, în cadrul American Psychological Association.

${ }^{2}$ În „Science”, 3 apr.; de asemenea, folosită de acesta în ședința din 13 apr. a Academiei de Științe din New York. Există o oarecare confuzie între terminațiile - genic și - genetic. Cred că distincția corectă este cea care aplică -genic la cazurile în care cuvîntul la care se afixează califică un termen folosit în mod activ, iar - genetic se aplică pentru semnificația pasivă. Așadar, agenților, cauzelor, influențelor etc. li se aplică ontogenic, filogenic etc., în vreme ce efectelor, consecințelor etc. li se aplică ontogenetic, filogenetic etc. 
tice. Acești factori sînt: mai întîi, agenții fizici și influențele din mediu, care acționează asupra organismului producînd modificări ale formei şi funcțiilor sale. Se includ aici toți agenții chimici, solicitările, contactele, constrîngerile de creștere, schimbările de temperatură etc. În măsura în care aceste forțe creează schimbări în organism, acestea pot fi considerate, în sens larg, fortuite sau accidentale. Avînd în vedere forțele care generează acești factori, propun să-i numim fizico-genetici. Teoria lui Spencer despre evoluția ontogenetică se întemeiază în cea mai mare parte pe apariția acțiunilor întîmplătoare, produse de astfel de influențe accidentale. În al doilea rînd, există o clasă de modificări ce apar din activitățile spontane ale organismului însuși, în procesul de execuție a funcțiilor congenitale normale. Aceste variații și adaptări se observă cu deosebire la plante, la organismele unicelulare și la copiii foarte mici. La aceste ființe pare a exista o ușurință și o propensiune a părților organismului către „a face față situației”, ca să spunem astfel, și a profita de circumstanțele din viața lor. Faptele au fost evidențiate de către Henslow, Pfeffer, Sachs (la plante), Binet, Bunge (la micro-organisme), Bernheim, Janet (în patologia umană), Baldwin (la copii; ref. b., cap. VI; a se vedea citările din ref. b., cap. IX și din Orr, Theory of Development, cap. IV). Propun ca aceste schimbări să fie numite neuro-genetice, accentuînd ceea ce este numit de către Romanes, Morgan și alții însuşire selectivă a sistemului nervos și a vieții, în general. În al treilea rînd, este vorba de marea serie de adaptări asigurate de factori conștienți, care pot fi grupate ca psibo-genetice. Procesele implicate aici sînt clasate în linii mari sub denumirea inteligență, adică imitație, influențe gregare, instrucție maternă, lecțiile plăcerii și ale durerii, ale experienței, în general, și raționare dinspre mijloace către scopuri etc.

În felul acesta, obținem următoarea schemă:

\section{Modificări ontogenetice. Factori ontogenetici.}

1. Fizico-genetic ......... Mecanic

2. Neuro-genetic ......... 2. Nervos

3. Psiho-genetic......... Inteligent

Imitaţie.

Plăcere și durere.

Rațiune.

Este evident că avem aici două chestiuni distincte, care apar imediat ce acceptăm existența modificărilor funcției sau a structurii pe parcursul evoluției ontogenetice: prima este chestiunea felului în care ajung aceste modificări să fie adaptative în viața individului. Altfel spus: Care este calea de creștere și de adaptare a individului, dată de bine cunoscuta lege a „întrebuințării și neîntrebuințării”? Privit din punct de vedere funcțional, organismul reușeșete cumva să se acomodeze la condițiile favorabile, să repete mișcările adaptative și astfel să crească în baza principiului întrebuințării. Acest fapt implică un soi de selecție, din bazinul variațiilor ontogenetice, a unora de un anumit tip - anumite funcții etc. Alte funcții și structuri posibile și în act decad prin neîntrebuințare. Oricare ar fi metoda prin care se produce acest fapt, putem susține în momentul de față, pur și simplu, că legea întrebuințării și a neîntrebuințării se aplică la evoluția ontogenetică și să folosim sintagma selecţie organică cu referire la comportamentul organismului în procesul de dobîndire de modalități noi sau de modificări ale funcției adaptative, cu efecte asupra structurii. Chestiunea căii pe care se petrece selecţia organică se pune mai jos (IV); aici, repet, doar presupunem ceea ce toți acceptă, într-o formă sau alta, anume că apar astfel de adaptări ale funcției-psihologul le numește acomodări, procese de învățare a noilor mișcări etc. Ajungem apoi la cea de-a doua chestiune, a locului acestor adaptări în teoria generală a evoluției.

Efectele selecției organice.-IÎn primul rînd, putem reține rezultatele acestui principiu în viața individuală a organismului.

1. Asigurarea adaptărilor și acomodărilor face ca organismul să rămînă în viață, în circumstanțe speciale (ref. b., ed. 1, p. 172 ș.urm.). Acest lucru este adevărat în toate cele trei sfere ale variației ontogenetice distinse în tabelul de mai sus. Vietățile care rezistă la „furtunile și solicitările” influențelor fizice ale mediului și la schimbările de mediu, pe calea modificărilor petrecute la nivelul funcțiilor lor congenitale sau al structurilor căpătate congenital, vor trăi; cele care nu reuşesc acest lucru nu vor supravieții. În sfera variațiilor neuro-genetice întîlnim o serie superbă de adaptări-atît ale organismelor inferioare, cît și ale celor superioare-, petrecute pe parcursul evoluției ontogenetice (ref. b., cap. IX). În sfera cea mai de sus, cea a inteligenței (care include toate felurile de fenomene ale conștiinței, trăirea plăcerii şi a durerii, imitaţia etc.), de asemenea aflăm acomodări individuale la o scară extraordinară, care culminează $\mathrm{cu}$ performanțele ingenioase ale voinței umane, ale 
invenției etc. Progresul copilului, în toate procesele care îl conduc spre starea de adult, ilustrează pe deplin această formă superioară de adaptare ontogenetică (ref. b., cap. X-XIII).

La organismele superioare, toate aceste etape sînt asociate, toate concurînd la a ține vietatea în viață.

2. Prin aceste mijloace sînt menținute în viață acele variații congenitale sau filogenetice care servesc modificărilor inteligente, imitative, adaptative și mecanice, de-a lungul vieții organismului care le deține. Astfel stînd lucrurile, alte variații congenitale nu sînt menținute. În felul acesta, în ontogeneza fiecărei generații (ref. c., d., e.) apar serii, mai mult sau mai puțin răspîndite, de variații determinate ${ }^{3}$.

Următoarele aplicații ale principiului ne conduc pe domeniul celui de-al doilea aspect, adică Filogenia.

II.

Filogenie: 'ereditate fizică._Luată separat de cea a eredității, în măsura în care este posibil, chestiunea evoluției filogenetice se referă la factorii care întradevăr apar în mersul evolutiv din generație în generație. Cea mai importantă serie de fapte, recent scoasă la lumină, este cea care arată ceea ce se numește variație determinată de la o generație la alta. Paleontologii au insistat asupra acesteia. Dintre cele două teorii curente asupra eredității, doar una, cea neolamarckiană-pe calea principiului moștenirii trăsăturilor dobîndite—a fost în măsură să explice schimbarea filogenetică determinată. Weismann admite că, în explicarea variațiilor necesare sau, după cum spune el, a „variațiilor potrivite în locul potrivit” („Monist”, ian., 1896), nu se poate considera că principiul selecției naturale ar acționa asupra organismelor rivale.

În ce mă privește, am susținut nuanțat că ipoteza variațiilor determinate ale funcției, în ontogeneză, dacă este subordonată principiului adaptării neurogenetice și psihogenetice, elimină nevoia de a apela la factorul lamarckian. De pildă, în cazul instinctelor, „dacă nu presupunem conștiența, atunci selecția naturală este inadecvată; dar dacă presupunem conștiența, atunci moștenirea trăsăturilor dobîndite este nenecesară” (ref. e.).

„Inteligența, care este chemată să ia locul instinctului și să-i dea naștere, folosește doar variațiile parțiale care tind în direcția instinctului; în acest fel inteligența completează astfel de coordonări parțiale, le face funcționale, ținind vietatea in viață. În termenii Profesorului Lloyd Morgan, acest lucru împiedică „apariția selecției naturale”. Astfel, presupunerea că inteligența este operativă se dovedește a fi doar presupunerea care face ca întrebuințarea-moștenire să devină nenecesară. Ținute astfel în viață, speciile au tot timpul necesar pentru perfecționarea variațiilor cerute de un instinct deplin. Iar atunci cînd înțelegem că variația solicitată nu se referă în măsură consistentă la nivelul muscular, ci la cel al conexiunilor centrale ale creierului-în cel mai bun caz fiind o uşoară variație cu scopuri funcționale-, ipoteza întrebuințării-moștenirii devine nu doar nenecesară, dar, consider, de-a dreptul inutilă (ref. d., p. 439). În ceea ce privește adaptarările, în general, „cei mai maleabili indivizi vor fi păstrați spre a opera lucrurile avantajoase pentru care au fost cel mai bine echipaţi de variaţiile lor, iar generația următoare va prezenta o accentuare a variațiilor tocmai în această direcție" (ref. c., p. 221).

Prin urmare, dinspre selecția organică obținem anumite rezultate în domeniul Filogeniei:

\section{Acest principiu asigură supraviețirea anumitor} linii de variație filogenetică determinată, în direcțiile adaptärilor ontogenetice determinate ale generațiilor anterioare. Deoarece sînt ținute în viață, variațiile folosite pentru adaptarea ontogenetică în generația anterioară sînt folosite mai mult în generația subsecventă (ref. c., d.). „Pe de o parte, variațiile congenitale se păstrează și devin efective prin utilizare pentru adaptările din existența individului; pe de altă parte,

\footnotetext{
${ }^{3}$ „Este necesar să avem în vedere modul în care anumite reacții ale unui singur organism pot fi selectate astfel încît organismul să se adapteze mai bine și să-și crească șansele de a supraviețui și de a se perpetua. Pentru început, să numim acest proces selecţie organică, prin contrast cu selecția naturală a tuturor organismelor. (...) Dacă selecția naturală ar lucra de una singură, fiecare schimbare din mediu ar elimina toate formele de viață cu excepția acelor organisme care, prin variație accidentală, au reacționat deja în chipul solicitat de condițiile schimbate—de fiecare dată noile organisme prezentînd variații, dar în nici un caz elemente noi din existența vechilor organisme. Pentru aceasta ar trebui să concepem (...) în organism cine știe ce modificare a vechilor reacții, petrecută sub influența noilor condiții. (...) În acest fel sîntem nevoiți să considerăm că noii stimuli provocați de schimbările mediului modifică ei înșiși reacțiile organismului. (...) Faptele arată că, pe parcursul existenței lor, organismele individuale dobîndesc noi adaptări, aceasta fiind prima noastră problemă. Dacă, în încercarea de a o rezolva, aflăm un principiu care poate totodată servi ca principiu al evoluției speciei, atunci l-am putea folosi împotriva oricărei «autosuficiențe a selecției naturale» sau în sprijinul ei” (ref. b., ed. 1, p. 175-176).
} 
adaptările devin congenitale prin progres continuu și prin rafinarea variației în aceleași linii funcționale precum cele a căror achiziție de către individ a fost pusă în act. Dar în nici unul dintre cazuri nu este nevoie să se asume factorul lamarckian" (ref. c.). De asemenea în cazurile de adaptare conștientă: „Ajungem la o perspectivă care, în cele din urmă, conferă evoluției organice un soi de direcție inteligentă, căci, dintre toate variațiile care tind în direcția unei adaptări, vor fi întărite și ținute în viață doar acelea pe care inteligența le susține și le foloseşte. Principiul valorii selective se aplică celorlalte sau unora dintre acestea. Selecția naturală, așadar, le elimină pe celelalte, evoluția viitoare a fiecărui stadiu din dezvoltarea unei specii trebuind să se petreacă în direcțiile astfel sprijinite de inteligență. La fel stau lucrurile și în cazul imitației. La nivel de specie vor supraviețui doar acele acțiuni imitative ale ființei care îi sînt folositoare, întrucît, în măsura în care imită acțiuni care sînt dăunătoare, ea va ajuta selecția naturală la propria eliminare. Deci, inteligența—și imitația care o copiază—va impune direcția de dezvoltare a instinctelor complexe chiar şi în teoria neo-darwinistă; și sub acest aspect spunem că conștiința este un factor" (ref. d.).

\section{Limitele variației fllogenetice devenind astfel} mai determinate, variațiile filogenetice ulterioare vor urma acest cadru, iar aceste variații vor fi iarăşsi folosite de selecția organică în vederea adaptării ontogenetice. Avem a face, aşadar, cu un continuu progres filogenetic în direcțiile stabilite de adaptarea ontogenetică (ref. c., d. și e.). „Inteligența completează coadaptările uşoare și le conferă valoare selectivă, dar nu le ferește de a dobîndi o mai mare valoare selectivă decît instinctele, reflexele etc., prin continuarea variației” (ref. e.). „Folosind coordonarea musculară, funcția imitativă completează și asigură adaptările, ține ființa în viață, previne «apariția selecției naturale», oferind astfel speciei timp pentru a obține variațiile necesare performanței depline a funcției instinctive” (ref. d.). Însă, „cu toate că-după cum s-a văzut-imitația conștientă previne apariția selecției naturale și, astfel, ține în viață ființele ale căror instincte nu dețin nivelul de performanță cerut pentru acțiunile acestora, ea nu ajută părților pe care le ajută instinctele speciale, și nici nu le împiedică să posede valoarea selectivă despre care vorbește Romanes. În acest sens, continuăm să considerăm că principiul selecției naturale este operativ în definiția mai largă a inteligenței-care încorporează orice imitaţie conști- entă, folosire a instrucției materne și tot felul de astfel de lucruri-, precum și în cea mai îngustă” (ref. e.).

3. Se elimină astfel complet factorul lamarckian, pînă la două șiruri de dovezi în favoarea acestuia. Mai întîi este compromisă dovada extrasă din funcție„întrebuințare și neîntrebuințare”-, de vreme ce, prin selecție organică, reapariția în generaţiile următoare a variațiilor fixate inițial în ontogeneză se explică fără moștenirea trăsăturilor dobîndite. La fel se petrec lucrurile cu dovada extrasă din paleontologie, care menționează întemeierea variaţiilor progresive pe întrebuințare și neîntrebuințare. Este compromisă apoi dovada extrasă din faptele variațiilor determinate, de vreme ce, prin acest principiu, astfel de variații în filogenie se păstrează fără moștenirea trăsăturilor dobîndite.

4. Acesta însă nu este preformism, in sensul vechi, de vreme ce adaptările petrecute in decursul evoluției ontogenetice, care "stabilesc" direcția de evoluție, constituie înnoiri parțiale sau totale ale funcției (cu toate că folosesc variațiile congenitale de structură). Ființele supraviețuiesc doar prin exercițiul noilor funcții și propagă și produc în continuare variații de structură, care, cu timpul, pot prelua congenital întreaga funcție, dimpreună cu structura care i se potrivește. Argumentul lui Romanes extras din co-adaptările parțiale și valoarea selectivă pare a fi valabil în cazul funcțiilor reflexe și instinctive (ref. d. și e.) și opus vechiului preformism sau perspectivei weismanniene, cu toate că acțiunea selecției organice-așa cum este explicată acum-îl face inoperant atunci cînd este avansat în sprijinul lamarckismului. „Ne putem imagina că ființele care apucau un obiect doar dintr-o parte, cu toate degetele, au descoperit-sub presiunea împrejurărilor şi pe măsura variațiilor care permiteau continuarea adaptării-cum să folosească degetul mare, opunîndu-l celorlalte, aşa cum facem noi. Să mai presupunem că acest lucru s-a dovedit atît de util încît toate progeniturile care nu puteau opera aşa au pierit; generația următoare, care a ajuns la maturitate, ar fi trebuit să fie îndeajuns de maleabilă, de inteligentă sau imitativă încît să facă mișcarea. Indivizii acestei generații ar fi trebuit să folosească aceleași mișcări de coordonare și să împiedice selecția naturală să acționeze pe pielea lor; prin urmare, instinctiva «opozabilitate a degetului mare», aşteptată indefint de către specii, ar fi putut fi dobîndită ca instinct pe deplin separat de întrebuinţare-moștenire” (ref. d.). „Am citat «opozabilitatea a degetului mare» deoarece se 
poate observa la copii anticiparea, prin inteligență și imitaţie, a întrebuinţării degetului mare în scopul adaptării, pe care probabil că celelalte primate o capătă prin instinct și pe care cred că un copil izolat și cu mintea slabă, să spunem, de asemenea ar căpăta-o prin instinct" (ref. d.).

5. De asemenea-deși cu greu îndrăznesc să mă aventurez într-un domeniu ce aparține atît de strict biologilor-, mi se pare că acest principiu ar putea să explice nu doar multe cazuri de räspîndire a variațiilor determinate, care apar brusc, să spunem, în depozitele fosile, dar și faptul că adesea variațiile par a fidiscontinue. De exemplu, să presupunem că anumite animale variază în ceea ce privește o anumită însușire, de la $a$ la $n$, în jurul unei medii $x$. Media $x$ ar constitui cazul cel mai probabil a fi păstrat în forma fosilă (socotind că sint mult mai multe de acest fel). Să presupunem o schimbare profundă a mediului, astfel încît doar variațiile din apropierea extremei $n$ se pot acomoda la ea şi pot trăi pînă la reproducere. Următoarea generație va prezenta, în consecință, variații în jurul mediei $n$. Și va fi mai probabil ca fosilele din această generaţie și din cele care-i urmează să fie ale unor organisme orînduite în jurul lui $n$. S-ar înregistra în acest caz o mare discontinuitate de-a lingul lanțului și o prevalență copleșitoare a acestor variații într-o direcție dată. Lucrul pare cu deosebire evident dacă avem în vedere că paleontologul nu are a face cu generații succesive, ci cu etape îndepărtate între ele, iar cel mai mic interval de timp de care putem avea cunoștință este îndeajuns de mare încît să genereze o nouă medie, $n$, a variației, multe generații în care să se înmulțească și să se adune fosilele ei reprezentative. Desigur, aceasta ar fi doar acțiunea selecției naturale asupra variațiilor preformate, în cazurile care nu implicau schimbări reale, la nivel structural și funcțional, dobînditepeparcursul ontogenezei; însă, în măsura în care astfel de adaptări onotogenetice erau acolo de fapt, amploarea diferenței dintre media $n$ și media $x$ ar fi şi mai mare, şi, prin urmare, resursele explicației-deopotrivă din brusca predominanță a noului tip și din discontinuitatea sa faţă de precedentul tip-ar crește semnificativ. Așadar, această soluție suplimentară se datorează factorului selecției organice.

De asemenea, se pare că putem folosi toate dovezile îndeobște menționate în favoarea originii funcționale a trăsăturilor specifice și a combinației de trăsături. În măsura în care lamarckienii au dovezi puternice aici, ele rămîn tot atît de puternice dacă selecția organică înlocuiește „moștenirea trăsăturilor dobîndite”. Lucrurile stau cu deosebire astfel atunci cind este vorba despre adaptările inteligente și imitative, precum în cazul instinctului. Aceasta „ar putea oferi motivul pentru care instinctele, de exemplu, sînt atît de des învecinate cu limitele speciilor. Structuri similare îşi întrebuinţează similar inteligența și tot similar acționează imitativ spre propriul bine. Așadar, interacțiunea acestori factori conștienți cu selecția naturală face ca definiția structurală, care reprezintă speciile, și definiția funcțională, care reprezintă instinctul, să coincidă în linii generale” (ref. e.).

6. Prin urmare, pare potrivit să numim influența selecției organice „un factor nou”; căci oferă o metodă de a dobîndi cîștiguri clare dinspre Filogenie prin adaptările Ontogeniei, care nu depinde de vreuna dintre cele două teorii curente. Adaptările ontogenetice sînt realmente noi, nu preformate, și sint cu adevărat reproduse în generațiile următoare, deși nu se moștenesc pe cale fizică.

III.

Ereditatea socială.-Se impune discuției încă o resursă a evoluţiei. Există la toate nivelele superioare ale evoluției anumite procese cooperative sau „sociale" care suplimentează sau se adaugă în mod direct la adaptările personale ale individului. La formele inferioare, fenomenul se numește gregaritate, la om, socialitate, iar la cele mai de jos forme (cu excepția plantelor), apar indici ai unui soi de acțiune imitativă și responsivă între vietățile aceleiaşi specii și din acelaşi habitat. În toate aceste cazuri este evident că celelalte vietăți constituie parte a mediului uneia și că multe acomodări neurogenetice și psihogenetice au legătură cu sau implică aceste alte vietăți. Principiul imitației capătă aici o importanță extraordinară; de asemenea, inteligența și voința; iar în chestiunile privitoare la om, cooperarea socială. Este limpede că atunci cînd vietățile tinere prezintă, într-un grad oarecare, aceste tendințe imitative, inteligente sau cvasisociale, ele sînt în stare să aleagă pentru sine, prin imitație, instrucție, experiență în general, funcțiile pe care părinții lor și alte vietăţi le exercită de față cu ele. Aceasta este deci o formă de adaptare ontogenetică; ea ține în viață ființele respective și produce varietăți determinate în chipul mai sus explicat. Prin urmare, constituie un exemplu de principiu general al 
selecției organice foarte special și, datorită largii sale aplicabilități, extrem de important.

Dar valoarea sa nu încetează aici. Ea ține în viață o serie de funcții care încă nu sînt sau nici nu vor deveni vreodată congenitale. Constituie un mijloc de transmitere extraorganică, din generație în generație. Este realmente o formă de ereditate deoarece 1) este o transmitere a funcțiilor fizice, dar fără a fi ereditate fizică. Are dreptul să se numească ereditate pentru următorul motiv: 2) influențează în mod direct ereditatea fizică, în felul menționat, adică ține în viață variațiile, deci stabilește direcția adaptării ontogenetice, prin aceasta influențînd direcția variațiilor congenitale disponibile ale următoarei generații, determinînd astfel dezvoltarea filogenetică. În consecință, am numit-o ereditate socială (ref. b., cap. XII; ref. c.).

Ereditatea socială, aşadar, constituie un climat ontogenetic mai mult sau mai puțin conservator, progresiv, asupra căruia putem face remarci:-

(1) Asigură adaptările indivizilor din toată lumea animală. „În loc să limităm această influență la oameni, trebuie s-o extindem la toate animalele gregare, la toate vietățile care au vreo capacitate de a imita și, în cele din urmă, la toate animalele care au suficientă conștiență încît să fie apte de adaptare; deoarece astfel de creaturi vor avea urmași care pot face la fel şi nu este nevoie să spunem că urmaşii trebuie să moștenească ceea ce părinții lor au făcut din inteligență, cînd ei înșiși pot face aceleași lucruri tot prin inteligență" (ref. f.).

(2) Tinde să stabilească direcția parcursului fllogenetic prin selecție organică, selecție sexuală etc., adică tinde nu doar să procure urmaşilor adaptările pe care adulții deja le au, ci și să producă adaptări care depind de cooperarea socială; așadar, variațiile in direcția socialității sînt selectate, devenind determinate. "Cînd ne gîndim că permanența unei deprinderi învățate de către un individ este în mare măsură condiționată de învăţarea aceleiași deprinderi de către alții (mai cu seamă de sex opus), în același mediu, observăm că trebuie să fi existat o recompensă enormă pentru variațiile de tip social-acelea care au adus indivizi diferiți într-un soi de acțiune conjugată sau cooperare. Acolo unde s-a întîmplat aşa, deprinderile sau păstrat și, totodată, au putut apărea noi variaţii, avînd întreaga forță a tendinței dublu ereditare" (ref. c.). De ce, de exemplu, nu apare mai repede o rasă de mulatri, care să ocupe zona de sud a Statelor Unite? $\mathrm{Nu}$ se datorează acest lucru simplei respingeri soci- ale a căsătoriilor dintre albi și negri? Eliminați sau întoarceți pe dos această influență a educației sau a imitației etc., iar rezultatul asupra filogeniei se va vădi și chiar va apărea la fosilele noastre atunci cînd, peste timp, vor fi dezgropate de către paleontologii eonilor ce vin!

(3) La om, devine legea evoluției sociale. „Weismann şi alții au arătat că influența reproducerii animalelor, privită sub aspectul instrucției maternale, al imitației, al cooperării gregare etc., este foarte importantă. Wallace insistă asupra faptelor pozitive care ilustrează «factorul imitativ»-cum l-am putea numi-în dezvoltarea individuală a animalelor tinere. Recent am susținut că Spencer și alții se înşală cînd susțin că progresul social necesită întrebuințarea-moștenire, de vreme ce acțiunile speciilor, dobîndite pe cale socială-mai cu seamă în ceea ce-l privește pe om-se transmit pe cale socială, generînd un soi de ereditate socială care o completează pe cea naturală” (ref. d.). „Sport”-ul social, geniul, este foarte adesea factorul de control în evoluția socială. Nu doar că stabilește direcția mersului viitor, ci poate ridica societatea la un nou nivel al împlinirilor” (ref. f.). „În ceea ce privește progresul intelectual și moral, argumentele în favoarea perspectivei eredităţii sociale par atît de puternice încît aș putea sugera o ipoteză, pe care o găsesc interesantă, chiar dacă s-ar putea să nu reziste. Este posibil ca dezvoltarea vieții sociale să nu se justifice din perspectiva unei a doua utilităţi, pe lîngă cea a utilităţii în lupta pentru existență, așa cum se înțelege îndeobşte, a doua utilitate fiind cea de a oferi fiecărei generații realizările trecutului pe care moștenirea naturală nu le poate transmite. Cînd începe viața socială, apare selecția artificială a celui neadaptat; acest principiu negativ începe să acționeze în mod direct împotriva progresului, după cum au arătat-o clar și recent autori preocupați de temele sociale. Astfel stînd lucrurile, este nevoie de o altă resursă alături de moștenirea naturală. Conform ipotezei mele, resursa necesară se găsește în standardele comune sau sociale ale realizării la care individul își adaptează dezvoltarea și la care este obligat să se supună. Acest lucru asigură progresul pe două căi: în primul rînd, făcînd individul să învețe ceea ce specia a învățat, prevenindu-se astfel regresul social; și, în al doilea rînd, răsplătind în mod direct variațiile accesibile social” (ref. c.).

(4) Cele două căi de asigurare a evoluției în direcții determinate-calea pur extra-organică a eredităţii 
sociale și calea prin care selecția organică, în general (deopotrivă prin adaptări sociale și prin alte adaptări ontogenetice), asigură fixarea variațiilor filogenetice, aşa cum au fost descrise mai sus-par a merge în paralel. Influența lor conjugată prezintă cel mai înalt grad de interes la nivelul instinctelor complexe (ref. d. și e.). La unele instincte întîlnim funcții în întregime reflexe sau congenitale, explicabile prin selecția organică. La nivelul altor instincte întîlnim doar coordonări parțiale, gata oferite de ereditate, și o situație în care ființa se bazează pe o resursă conștientă oarecare (imitație, instrucție etc.) pentru activarea instinctului. Dar, pe măsură ce intrăm în spațiul evoluției filogenetice, pot fi prezente ambele procese pentru aceeași funcție; inteligența vietății o poate face să realizeze în mod conștient ceea ce realizează și în mod instinctiv. În aceste situații, folosul suplimentar cîștigat prin dubla performanță explică dublarea. Aceasta a apărut fie 1) prin acumularea variațiilor congenitale în vietățile care deja făceau acțiunea (prin adaptare ontogenetică și transmisă social), fie 2) invers. La animale, transmiterea socială pare a fi utilă mai ales pentru a face specia capabilă să dobîndească lent instincte, în direcții determinate, ferind-o de acțiunea selecției naturale. Prin urmare, ereditatea socială este factorul minor, care servește eredității biologice. La om însă este invers. Transmiterea socială este factorul important, iar echipamentul congenital al instinctelor este, de fapt, întrerupt, spre a permite plasticitatea necesară ființei umane pentru învățare socială. Așadar, în toate situațiile sînt prezenți ambii factori, dar invers proporțional. Cum spune Preyer: „cu cît aduce în lume mai multe feluri de mișcări coordonate, cu atît mai puține va fi capabil animalul să învețe apoi”. Copilul este animalul care moștenește cel mai mic număr de coordonări congenitale, dar este cel care învață cel mai mare număr” (ref. b., p. 297).

„În măsura în care viața timpurie a copilului poate fi luată drept indicator al factorilor evoluției, este foarte probabil ca principala funcție a conștiinței să fie aceea de a-l face apt să învețe lucruri pe care eraditatea naturală nu reușește să le transmită; iar în copil, faptul că conștiința este mijlocul esențial al întregii învățări se corelează cu celălalt fapt: că copilul este vietatea căreia ereditatea naturală îi dă cele mai puține funcții independente. Îndrăznesc să vorbesc cu deplină încredere doar în această chestiune, însă același punct de vedere a fost susținut de către Weis- mann și alții în domeniul biologiei pure. Echipamentul instinctual al animalelor inferioare este înlocuit de către conștiință cu plasticitatea la învățare. Astfel, mi se pare că dovezile indică o anumită inversare a proporțiilor între importanța conștiinței și nevoia moștenirii trăsăturilor, ca factori ai evoluției” (ref. g.).

„Putem plasa fenomenul biologic al copilăriei sub cupola acestei concepții generale, cu întreaga sa semnificație evolutivă: plasticitatea ridicată a puiului de mamifer, spre deosebire de echipamentul instinctual foarte dezvoltat al celorlalte tipuri de progenituri; grija, instrucția și exemplul materne de pe parcursul perioadei de dependență; realizările extrem de graduale ale activităților de auto-întreținere, în condiții în care activităţile sociale sînt absolut esențiale. Tot acest fond al teoriei evoluției poate fi utilizat spre a confirma această perspectivă” (ref. c.).

Dar aceste două influențe procură o dublă resursă împotriva neo-lamarckismului. Și nu văd nimic în calea considerării selecției organice-din care ambele aceste resurse decurg-ca fiind o complinire suficientă a principiului selecției naturale. În orice caz, relația care o leagă de selecția naturală face obiectul remarcilor de mai jos" (V).

„De aceea, susţinem că există două mari tipuri de influențe, fiecare în chip ereditar. Există o ereditate naturală, prin care variațiile se transmit congenital o dată cu dotările originale; și există o ereditate socială, prin care funcțiile social dobîndite (adică pe cale imitativă, acoperind toate achizițiile conștiente petrecute ca urmare a interacțiunilor cu alte animale) sint transmise pe cale, de asemenea, socială. Una este filogenetică, cealaltă este ontogenetică. Dar aceste două direcții de influență ereditară nu sînt nici separate, nici lipsite de influențe reciproce. Pe de o parte, variațiile congenitale sînt ținute în viață și făcute să fie efective prin întrebuințarea lor conștientă, în scopul adaptărilor inteligente și imitative din viața individului. De cealaltă parte, adaptările inteligente şi imitative devin congenitale prin continuarea mersului înainte și rafinarea variației în aceleași direcții de funcționare cu cele în vederea cărora au fost achiziționate de către individ. În acest caz nu mai este nevoie de asumarea factorului lamarckian” (ref. d.).

„Singurul obstacol pe care îl văd în calea învățării, la copil, a tot ceea ce-i cere viața socială este tocmai lucrul pentru care pledează susținătorii lamarckismului: moștenirea trăsăturilor dobîndite. Aceasta, 
deoarece o astfel de moștenire tinde să lege substanța nervoasă a copilului în fome fixe, rămînîndu-i mai puțină sau chiar deloc substanță maleabilă, spre a învăţa. Astfel, în fapt, instinctul s-a dezvoltat puternic o dată cu animalele, acestea neavînd forța de a învăța ceva nou, numai în trucît sistemul lor nervos nu se află în starea mobilă reprezentată de conștiința înaltă. Ele au instinct, și prea puțin altceva” (ref. c.).

\section{IV.}

Procesul selecției organice. - Pînă acum am avut a face exclusiv cu fapte. Recunoscînd anumite fapte, am obținut o perspectivă care consideră că selecția ontogenetică este un factor important al evoluției. Fără a prejudicia în vreun fel dovezile factuale, ne putem întreba dacă funcționarea organismului este realmente direcționată către producerea selecțiilor sau adaptărilor sale organice. Întrebarea este pur şi simplu aceasta: din multitudinea de posibile schimbări ontogenetice pe care le-ar putea suferi și le suferă, cum şi le asigură organismul pe cele care sînt adaptative? De fapt, întreaga creștere a individului și toate achizițiile motorii dobîndite arată că reușește să o facă. Următoarea întrebare este: cum? Înainte de a răspunde trebuie să accentuez că poziția adoptată în paginile anterioare-care face din adaptarea ontogenetică un factor al evoluției-nu este parte a soluției la următoarea întrebare, despre felul în care sînt asigurate adaptările. De răspunsul la această ultimă întrebare depind unele clarificări cu privire la interpretările actelor înseși. Așadar, am întrebat cum acționează, de fapt, selecția organică, în cazul unei anumite adaptări a unei anumite vietăți (ref. a., b., cap. VII, XIII, f. și g.).

Susțin că organismul are o cale de a face aceasta, iar aceasta îi este proprie. În lucrarea la care trimit (b.), chestiunea este elaborată într-o asemenea măsură încît nu este nevoie să repet detaliile aici. Probabil că cititorii au văzut și rezumatul ei, din (f.). Se înregistrează un fapt de fiziologie care, luat împreună cu faptele de psihologie, servește la a arăta calea adaptărilor sau acomodărilor organismului individual. Organismul concentrează energiile în locul stimulat, în funcție de continuarea condițiilor, mișcărilor, stimulărilor care sînt benefice în chip vital sau în funcție de încetarea condițiilor, mișcărilor, stimulărilor care sînt deprimante şi nocive la nivel vital. În cazul condițiilor benefice întîlnim o creștere generală a mişcării, o descărcare în exces a energiilor de mișcare in canalele deja deschise și obişnuite; iar o dată cu aceasta, sub aspect psibologic, conștiința plăcută și atenția. Atenția față de membru este însoțită de creșterea activității vasomotoare, cu o mai mare forță musculară, și de creșterea dinamogenică generală a acelui membru. „Gîndul la o mișcare tinde să descarce în canale aproape tot atîta energie motorie cît este necesară pentru efectuarea acelei mișcări” (ref. c.). Prin această concentrație organică și prin acest exces de mișcare devin posibile multe combinații și variații, din care pot fi selectate pentru utilitatea lor mișcările avantajoase și adaptative. Acestea, apoi, reîmprospătează plăcerea, stimulează asocierile plăcute și, iarăși, stimulează atenția; prin aceste influențe, mișcările adaptative astfel impulsionate sînt selectate și devin achiziții permanente. Această formă de concentrare a energiei în locurile stimulate, cu rezultatul reînnoirii, prin mișcări, a condițiilor dătătoare de plăcere și profitabile, și cu reluările subsecvente ale mișcărilor, se numește reacție circulară ${ }^{4}$ (ref. a. și b.). Romanes a evidențiat că proprietatea selectivă este de natură să caracterizeze și să diferenţieze viața. Ea caracterizează răspunsurile organismului, oricit de slabe ar fi, la orice stimul-chiar și cele mecanice și chimice (fizicogenice). Pfeffer a dovedit chiar și la plante existența unei asemenea determinări a energiei către părțile stimulate. La animelele superioare, aceasta se află întocmai reprodusă în reacția nervoasă observată în imitație și-prin procesele de asociere, substituție etc.-în toate actele mentale superioare ce implică inteligența și voința. Acestea se dezvoltă filogenetic, ca variaţii a căror direcție este constant determinată de această formă a adaptării în ontogeneză. Dacă lucrurile stau astfel—iar factorii biologici par să o confirme-, avem în fața ochilor procesul adaptativ al vieții, acest proces fiind cel cu care a fost asociată evoluția vieții mentale.

Urmează că cele trei forme de adaptare ontogenetică anterior distinse-fizicogenetică, neurogenetică, psihogenetică-implică din partea organismului tipul de răspuns observat în această reacție circulară cu exces de descărcare; şi astfel ajungem la o lege generală a adaptării ontogenetice și a selecției organice. „Acomodarea unui organism la o nouă stimulare este asigurată nu de către selecția acestei stimulari anti-

\footnotetext{
${ }^{4}$ Opusă stărilor retractile și depresive, produse în condiții dăunătoare și dureroase.
} 
cipate (nici a mișcărilor necesare), ci de reactivarea ei printr-o descărcare a energiilor organismului, concentrate atît cît este nevoie pentru ca să stimuleze excesiv organele (muşchi etc.) cele mai pregătite, prin deprinderile anterioare, să suporte iarăși această stimulare (unde stimulare se referă la condiția favorabilă adaptării). După cîteva încercări, copilul, de pildă, dobîndește deprinderea dorită, mereu mai aproape de perfecțiune, iar mișcările excesive și inutile însoțitoare dispar. Acesta este tipul de selecție pe care inteligența îl face în achiziția de noi mișcărì” (ref. b., p. 179 și f.).

În consecință, toate adaptările ontogenetice sînt neurogenetice ${ }^{5}$. Legea generală a excesului motor este una a superproducției; din mișcări produse în exces, supraviețuiesc adaptările; acestea stabilesc direcția determinată a ontogenezei; și, de asemenea, prin supraviețuirea lor, aceeași determinare a direcției se stabilește în filogeneză.

Următorul citat, dintr-un articol anterior (ref. g.) va arăta unele dintre implicaţiile acestei poziții:

„Faptul că există un anumit principiu general care funcționează de-a lungul tuturor adaptărilor mișcărilor pe care le face orice vietate este arătat chiar de unitatea organismului în sine. Principiul deprinderii poate fi recunoscut într-un mod general, care permite organismului să facă lucruri noi fără a renunța cu totul la ceea ce a achiziționat deja. Acest lucru înseamnă că vechile deprinderi trebuie să se păstreze în chip semnificativ în noile funcții; că la toate funcțiile noi se ajunge prin modificări graduale. Mergem mai departe și spunem că singura cale prin care aceste modificări pot fi deprinse în întregime este un soi de interacțiune a organismului cu mediul său. Acum, dacă ne întrebăm despre felul în care stimulii din mediu pot produce noi mișcări adaptative, avem răspunsul lui Spencer și Bain-unul direct confirmat, cred, dincolo de orice îndoială, de studiul amîndurora asupra copilului și a adultului: prin selecția mișcărilor potrivite din rîndul mișcărilor produse în exces, adică din variațiile mișcării. Acceptînd acest lucru, în continuare avem a ne întreba: Cum ajung aceste variații ale mișcării a fi produse atunci cînd este nevoie de ele? ${ }^{6}$ Și, o dată cu aceasta, întrebarea: Cum păstreză organismul continuitatea acelor mișcări care sînt astfel selectate și cum le suprimă pe cele care nu sînt selectate?

Acestea sînt cele două întrebări la care biologii nu reușesc să răspundă. Dar prin forța faptelor sîntem conduși la ipoteza «forței conștiente», a «autodezvoltării», a lui Henslow, și a «tendinței directoare», a Școlii americane-toate, aspecte ale noului vitalism pe care doar aceste întrebări și faptele pe care se întemeiază îl împing în linia întîi. Avem oare ceva limpede-extras din studiul individului din perspectivă psihologică-cu care să înlocuim aceste sintagme vag biologice? Spencer a dat un răspuns general la a doua întrebare, demult deja, spunînd că, în conștiință, funcția plăcerii și a durerii este de a menține în act anumite acțiuni sau mișcări și de a le suprima pe altele.

Dar imediat ce ne punem întrebări mai detaliate asupra reacțiilor de plăcere și de durere dăm peste un posibil răspuns la prima întrebare, și anume aceea referitoare la modul în care ajunge organismul să producă tipul și felul de mișcări solicitate de mediumişcarea variațiilor, cînd și unde sînt ele cerute. Plăcerea sau durerea produsă de către un stimul—și, de asemenea, de mişcare, deoarece utilitatea mişcării este întotdeauna aceea care asigură stimularea cutărui sau cutărui fel—nu duce la mișcări difuze, neutre și vagi, după cum presupun Spencer și Bain, lucru deopotrivă controversat atît pentru mișcările copiilor, cît și pentru cele ale vietăților unicelulare. Există diferențe caracteristice la nivelul mișcărilor vitale, oriunde le-am întîlni. Chiar dacă ar fi existat mișcările protoplasmatice nediferențiate despre care vorbește dl Spencer, selecția naturală le-ar fi pus capăt destul de devreme. Întotdeauna există o antiteză carateristică la nivelul mișcărilor vitale. Sănătoase, debordante, copleșitoare, expansive, efectele vitale sint asociate cu plăcerea; și, dimpotrivă, retractile, depresive, contractate, diminuatoare, efectele vitale sînt asociate cu durerea. Aceasta este întocmai starea

\footnotetext{
${ }^{5}$ Desigur, cu excepția acelor influențe fizice puternic constrîngătoare, sub a căror acțiune organismul este neputincios.

${ }^{6}$ Tocmai aceasta este întrebarea la care caută Weismann răspuns (în ceea ce privește furnizarea de variații, în formele cerute de către paleontologi), prin doctrina „selecției germinale” („Monist”, ian., 1896). De ce astfel de aplicații ale principiului selecție naturale la variațiile în părțile și în funcțiile unui organism individual nu sînt la fel de rezonabile și de legitime precum variațiile celorlalte organisme? Împotriva „selecției germinale” aș putea spune că, în cazul în care adaptarea ontogenetică stabilește direcția variațiilor filogenetice supraviețuitoare (așa cum se susține în acest articol), ipoteza selecției germinale devine nenecesară. Această perspectivă vede în operațiunea de selecție a funcțiilor în ontogenie modalitățile de asigurare „a variaților cînd și unde este nevoie de ele”, în vreme ce Weismann presupune competiția unităților germinale.
} 
de lucruri pe care o cere teoria selecției mișcărilor din supraproducția de mișcări: vitalitatea crescută, reprezentată de plăcere, ar trebui să genereze excesul de mișcări, din care se selectează noile adaptări; iar vitalitatea scăzută, reprezentată de durere, ar trebui să aibă efectul invers, adică scăderea energiei și suprimarea mișcării ${ }^{7}$.

Prin urmare, dacă spunem că există un tip de reacție prezent în tot ce este viu, îi putem da un nume descripitiv general, adică reacție circulară; importanța sa pentru evoluție constă tocmai în faptul că nu este un răspuns motor aleatoriu la orice stimulare, ci că distinge, prin chiar forma și intensitatea ei, între simulările bune și rele din punct de vedere vital, tinzînd să rețină stimulările bune și să ocolească și astfel să suprime ceea ce este rău. Termenul circular este folosit pentru a reliefa calea pe care o astfel de reacție tinde să se mențină continuă, reproducînd condițiile propriei stimulări. Ea reprezintă obişnuința, de vreme ce tinde să mențină vechile mișcări; dar asigură noi adaptări, de vreme ce procură supraproducția de variații ale mișcării pentru operația de selecție. De vreme ce necesită cooperarea directă a organismului însuși, am numit acest tip de selecție selecție organică”.

Avantajele acestei perspective par a fi cele ce urmează:

1. Oferă o metodă a adaptărilor individuale ale funcțiilor conformă principiului legii supraproducției și supraviețirii, acum atît de bine stabilit in cazul organismelor aflate în competiție.

2. Reduce evoluția nervoasă și mentală la termeni strict paraleli. Întrebuințarea inteligentă a variațiilor filogenetice, în scopuri funcționale și în chipul indicat, pune preț pe variațiile care pot fi astfel folosite și, așadar, stabilește progresul filogenetic în direcții de constant îmbunătățtită dezvoltare mentală. Reacția circulară, care este metoda adaptării inteligente, se leagă de variația în serii de căi complexe, care, din perspectivă filogenetică, reprezintă dezvoltarea funcții- lor mentale cunoscute ca memorie, imaginație, conceptualizare, gîndire etc. Prin urmare, ajungem la o filogenie a minții, care continuă în direcția stabilită de ontogenia minții ${ }^{8}$, întocmai precum pe latura organică filogenia organismului asumă direcția determinată din adaptările ontogenetice ale organismului. Și de vreme ce principiul selecției organice este singurul care acționează prin aceleași funcții-spre a stabili direcția ambelor filogenii, fizice și mentale-, cele două evoluții nu sînt două, ci una singură. Așadar, evoluția nu este mai mult biologică decît este psihologică (ref. b., cap. X, XI, mai ales p. 383-388).

3. Asigură relația structurii cu funcția cerută de principiul „întrebuinţării și neîntrebuinţării” în ontogenie.

4. Singura teorie alternativă a adaptărilor individului este cea a "hazardului”, pe de o parte, și cea a „actului creator” al conștiinței, de cealaltă. Hazardul este respins de toate faptele care arată că organismul nu așteaptă întîmplarea, ci acționează direct și produce noi adaptări la mediu. Mai mult, adaptările ontogenetice sînt determinate, ele continuîndu-se în linii progresiv definite. Cred că pînă și un studiu sumar al copilului ar trezi la realitate pe orice susținător al teoriei „hazardului”. Dar cealaltă teorie, care susține că conștiința face adaptări și schimbă structuri în mod direct, prin al ei flat, este contrazisă de psihologia mișcării voluntare (ref. d., f., g.). Conștiința nu poate produce mișcare fără a avea mai întîi experiența adecvată a acelei mișcări, spre a servi ca stimul pentru inervarea centrilor motori respectivi. „Acest lucru nu mai constituie obiect de dispută; deoarece cazurile patologice arată că, exceptînd situaţia în care vreo idee adecvată a unei mișcări vechi făcute de aceiași mușchi (sau, prin asociere, vreo altă idee care îi ține locul) este adusă la suprafață, inteligența este neputincioasă. $\mathrm{Nu}$ doar că nu poate executa mișcări noi, dar nu poate nici măcar să repete vechile mișcări intrate în deprindere. Putem spune deci

\footnotetext{
${ }^{7}$ Probabil că originea acestei antiteze se află în limitarea și scăderea proceselor nutritive. „Constatăm că dacă prin organism înțelegem ceva aflat pur și simplu în contracție sau excitație, al cărui ciclu de mișcări este menținut printr-un fel de procese nutritive furnizate de mediu—absorbție, acțiunea chimică a oxigenului atmosferic etc.—și a cărui existență este amenințată de pericolele contactului şi ale mai-știu-eu-cui, primul lucru care trebuie făcut este să se asigure o aprovizionare regulată a proceselor nutritive și să se evite acele contacte. Dar organismul poate să nu facă nimic altceva decît să se miște—ca întreg sau numai cu unele parți. Atunci, așadar, dacă una dintre acele vietăți devine mai potrivită decît o alta pentru a supraviețui, aceea este vietatea care prin mișcările ei își asigură mai multe procese nutritive și evită mai multe contacte periculoase. Dar mișcările către sursa de stimuli favorizează stimularea, iar mișcările care îndepărtează de contacte întrerup contactele! Natura selectează aceste organisme; cum ar putea face altfel? ... Așadar, nu avem altceva de făcut decît să presupunem că procesele de creștere nutritivă sînt, pe calea selecției naturale, secătuite în expansiunile organice, pînă la obținerea diviziunii mișcărilor, care reprezintă această adaptare bifurcată de mai înainte (ref. b., p. 201).

${ }^{8}$ Prof. C.S. Minot îmi sugerează că termenii ontopsibic și filopsibic ar putea fi potriviți pentru a marca această distincție.
} 
că adaptarea inteligentă nu creează coordonare; ea doar face funcțională întrebuințarea coordonărilor care deja erau alternativ prezente în dotarea vietăţii. Interpretînd acestea în termenii variaţiilor congenitale, putem spune că variațiile pe care le folosește inteligența constituie posibilități alternativ prezente ale mişcării musculare" (ref. d.). Prin urmare, singura cale posibilă prin care poate fi executată o mișcare cu adevărat nouă este executarea mişcării deja posibile intr-un mod atît de excesiv și cu atît de multe varietățti combinatorii etc., încît să poată genera noi adaptări.

5. Mi se pare că problema reia condițiile care l-au condus pe Darwin la principiul selecției naturale. Înainte de Darwin, alternativele erau „hazardul” și „creația specială”. Soluția a apărut dinspre „supraproducția și supraviețuirea celui mai adaptat”. La fel și în acest caz. Să luăm un exemplu. Fiecare copil are de învățat cum să scrie. Dacă el depinde de arbitrariul mișcărilor mîinilor, nu va învăța să scrie niciodată. Pe de altă parte însă, el nu poate scrie pur și simplu numai vrînd să facă acest lucru; ar putea să vrea la nesfîrșit, fără a produce o „creație specială” sau o mișcare musculară. Ceea ce face el, de fapt, este să își întrebuințteze mîna în multe modalități posibile, pe cît de aproape poate de calea cerută; iar de la aceste mișcări abundent produse și după excesiv de variate și de numeroase încercări, el selectează treptat și fixează puținele succese pe care a reușit să le aibă în direcția scrierii corecte. Este o lungă și foarte laborioasă acumulare de uşoare selecții organice dinspre mișcările abundent produse (ref., cu detalii asupra scrierii de mînă, b., cap. V, de asemenea, b., p. 373 ș.urm.).

6. Singurul sprijin la care mai poate apela teoria că ceea ce numim conștiință este un soi de actus purus, vine din partea susținerii ideii că aceasta direcționează energiile creierului sau selectează între posibilele alternative ale mișcării; dar în afară de obiecția că direcționarea mişcării este tot atît de dificilă ca executarea ei (căci numai o forță nu ar putea elibera sau direcționa energiile creierului), nu aflăm nici o necesitate de acest fel. Atenția este cea care determină mișcarea particulară în evoluția organismelor, iar atenţia nu mai este considerată un actus purus, fără procese cerebrale care s-o însoțească. Atenția este o funcție a amintirilor, mișcărilor, experiențelor organice. $\mathrm{Nu}$ sîntem atenți la un lucru deoarece l-am selectat deja sau pentru că îl selectează atenția; ci $̂ l l$ selectăm întrucît-fiind noi conștiință și organismsîntem atenți la el. „Este limpede că această doctrină a selecției aplicată la mișcarea musculară se îndepărtează de orice nevoie de a susține că conștiința direcționează cu adevărat energia creierului. Nevoia unei astfel de direcționări mi se pare tot atît de artificială pe cît a arătat Darwin că este nevoia creaţiei speciale pentru adaptările teleologice ale diferitelor specii. Dînd la o parte această nevoie-atît în cazul presupusului factor creator, cît și în cazul de față-, chestiunea relației conștiinței cu creierul devine una metafizică, tot aşa cum cea a teleologiei în natură devine metafizică; și nu este deloc profitabil ca știința să se încarce cu ea. Știința biologiei, ca și a psihologiei, ar trebui să fie mulțumită că lucrurile stau astfel, nu-i aşa?” (ref. f.; pentru chestiunea metafizică, g.).

\section{V.}

Un cuvînt asupra relației principiului selecției organice cu selecția naturală. Se consideră prea adesea că selecția naturală este un factor pozitiv. Ea nu este un factor pozitiv; este pe deplin negativ. Este doar o evidențiere a ceea ce se petrece cînd un organism nu are calificările necesare supraviețuirii în condiții de viață date; nu definește ca fiind pozitive calificările ce dau unui alt organism capacitatea de supraviețuire. Presupunînd că principiul selecției naturale se aplică în toate situațiile și spunînd că, în conformitate cu acesta, un organism va pieri dacă nu are calificările necesare, tot rămîne să aflăm, în acest caz, care sînt calificările pe care ar trebui să le aibă acel organism pentru a putea rămîne în viață. Așadar, putem spune că mijloacele de supraviețuire constituie întotdeauna o chestiune suplimentară faţă de constatarea negativă a acțiunii selecției naturale.

Desigur, aceastei din urmă chestiuni încearcă să-i răspundă teoria variaţiilor. Calificările pozitive pe care le dezvoltă organismul ca variații congenitale de un anumit tip, ce fac organismul să poată face față condițiilor de viață: aceasta este latura pozitivă a darwinismului, în vreme ce principiul selecției naturale este latura negativă.

Principala forță a selecției organice se află în relația sa cu teoria variațiilor, iar nu cu cea a selecției naturale. Selecția organică prezintă o nouă calificare de un tip pozitiv, care face ca organismul să fie în măsură să facă față mediului, în vreme ce selecția naturală rămîne exact ce a fost, legea negativă care spune că, dacă organismul nu reușește să supraviețuiască, atunci moare; față de o astfel de calificare din partea 
organismului, selecția organică prezintă mai multe aspecte interesante.

1. Dacă susținem, după cum am făcut-o mai sus, că metoda selecției organice este mereu aceeaşi (adică are o metodă naturală), fiind mereu împlinită printrun fel tipic de proces nervos (adică fiind mereu neurogenetică), atunci ne putem întreba dacă nu cumva această formă de proces nervos-și conștiința care se manifestă o dată cu el—ar putea fi o variație ce apare devreme în seriile filogenetice. Am arătat în altă parte (ref. b., p. 200 ș.urm., și 208 ș.urm.) că, cel mai probabil, lucrurile stau astfel. Organismele care nu au avut vreo formă de răspuns selectiv la ceea ce era benefic în mediu, spre deosebire de ceea ce era dăunător, nu au putut ajunge prea departe; în momentul în care a apărut o astfel de variație, ea a dominat imediat. Așadar, putem spune fie că proprietatea selecției nervoase, cu conștiință, este o variație, fie că aceasta este o dotare fundamentală în vederea vieții și o parte a misterului ei final. „Inteligența joacă un rol remarcabil. Ea însăși este-după cum am văzut-o variație congenitală, dar este și un factor important al adaptării personale a individului, atît la mediul fizic, cît și la cel social" (ref. d.).

„Primul (instinctul) reprezintă o tendință către variație a creierului în direcția conexiunilor stabile între anumiţi centri senzitivi și anumite grupe de mușchi coordonați. Această tendinţă este încorporată în materia albă și în centrii creierului inferior. Celălalt (inteligența) reprezintă tendința către variație în direcția posibilităților alternative de conectare a centrilor creierului cu aceleași grupe musculare coordonate sau cu unele similare. Această tendință este încorporată în cortexul emisferelor" (ref. d.).

2. Oricum am considera adaptarea ontogenetică prin reacție selectivă și conștientă, fie ca variație, fie ca aspect final al vieții, ea este o calificare vitală de tip extraordinar. Ea deschide o nouă sferă în ceea ce privește aplicarea la organisme a principiului negativ al selecției naturale, adică cu privire la ceea ce pot face ele mai degrabă decît la ce sînt ele; către noua întrebuințare pe care o dau acestea funcțiilor lor congenitale, mai degrabă decît către simpla deținere a funcțiilor (ref. b., p. 202 ș.urm.). Prețul este pus mai degrabă pe plasticitatea congenitală și adaptabilitatea funcției, decît pe fixitatea congenitală a funcției; iar această adaptabilitate îşi atinge culmea prin inteligență.

3. Ea mai deschide calea acțiunii selecției naturale-în continuare privită ca principiu negativ-prin supraviețuirea anumitor reacții supraproduse și modificate ale organismului, prin care se asigură determinarea creșterii organismului însuși și parcursul vieții. Dacă puiul de găină tînăr imită rața în loc să imite găina, va pieri, căci el poate învăța doar acele lucruri noi pe care i le permite dotarea, nu să înoate. De aceea trebuie selectate acțiunile și adaptările posibile puiului de găină în ontogenie. Am văzut felul în care poate avea loc o anumită competiție a funcțiilor, cu supraviețuirea celei mai adaptate. Dar aceasta este o acțiune a selecției naturale. $\mathrm{Nu}-\mathrm{mi}$ dau seama cum poate Henslow, de pildă, să ajungă la așa-numitele „autoadaptări”deosebite de "creația specială”-, care nu fac decît să justifice un atac la adresa selecției naturale. Spre a trăi, chiar și plantele trebuie să crească în direcții determinate sau selectate.

4. În sfirșit, putem spune că selecția organică-ea însăşi, probabil, o variaţie congenitală (sau o dotare originală)—acționează în direcția asigurării noilor calificări pentru supraviețuire ale ființei; iar rezulatele ei foarte bune provin din asigurarea unei noi aplicări a principiului selecției naturale la posibilele modificări pe care organismul este în stare să le suporte. Romanes spune: „este imposibil ca ereditatea să fi prevăzut dinainte inovațiile sau modificările propriei mașinării de-a lungul vieții unui anumit individ”. La aceasta sîntem obligați să răspundem, rezumîndașa cum am făcut înainte (ref. b., p. 220): atingem „doar starea de lucruri pe care Romanes le declară imposibile-ereditatea furnizînd modificarea propriei mașinării. Ereditatea nu doar lasă viitorului libertatea de a face modificări, ci îi și procură o cale de a trăi o viață în care modificările vor apărea negreșit.

\section{VI.}

Chestiunea terminologică. - Anticipez critici din pricina faptului că am folosit în acest articol mai mulți termeni noi. De fapt, unul sau doi dintre aceștia au fost deja criticați. Cu toate acestea, cred că noutatea termenilor este de preferat ambiguității conceptelor. Și de fiecare dată termenul nou este destinat să marcheze un sens real pe care nici un termen curent nu pare a-l exprima. Luînd pe rînd acești termeni și încercînd definirea lor, așa cum i-am folosit, se va vedea dacă întrebuințarea lor este justificată de fiecare dată; dacă nu, voi fi foarte bucuros să-i abandonez.

Selecție organică-Procesul de adaptare ontogenetică, considerat a menține organismele individuale 
în viaţă și a asigura, astfel, linii determinate de variație în generațiile subsecvente. Prin urmare, selecția organică este un principiu general al evoluției, care constituie un substitut direct al factorului lamarckian, în cele mai multe, dacă nu în toate, situațiile. Dacă acesta este într-adevăr un factor nou, atunci merită un nume nou, oricît de îngustă se va dovedi în cele din urmă a-i fi sfera. Folosirea în sintagmă a cuvîntului organic a fost sugerată de faptul că organismul însuși cooperează la formarea adaptărilor care se produc și, de asemenea, de faptul că, la nivelul rezultatelor, organismul însuși este selectat-de vreme ce organismele care nu-și asigură adaptările pier ca urmare a principiului selecției naturale. Cuvintul selecție, folosit în sintagmă, este potrivit din exact aceleași două motive.

Ereditate socială-Achiziția funcțiilor din mediul social, de asemenea considerată ca o metodă de a determina variațiile filogenetice. Este o formă de selecție organică, însă merită un nume special datorită căii speciale pe care operează. Este realmente ereditate, de vreme ce influențează direcția variației filogenetice prin păstrarea în viață a organismelor adaptate social, cînd altele, care nu se adaptează astfel, sînt eliminate. Este de asemenea ereditate de vreme ce constituie o continuă influență din generație în generație. Animalele pot fi ținute în viață, să spunem, doar într-un mediu dat de cooperarea socială; ele transmit posterității acest tip social de variație; în consecințtă, adaptarea socială stabilește direcția filogeniei fizice, iar ereditatea fizică este parțial determinată de acest factor. În continuare, procesul este, în tot acest timp, din generație în generație, ajutat de lanțul continuu de transmiteri extraorganice sau pur sociale. Acestea sînt rațiuni potrivite pentru a marca această influență cu un nume.

De ceilalți termeni nu mă îngrijesc la fel de mult. Fizicogenetic, neurogenetic, psihogenetic și corelatele lor în -genic mi se par convenabili pentru a marca distincții care-dincolo de transparența termenilor, dacă ei ar fi lipsit-ar fi implicat fraze lungi. Sintagma reacție circulară a fost bine primită printre psihologi și considerată potrivită. Acomodare este de asemenea curent printre psihologi, referindu-se la adaptări uni-funcționale, mai ales în zona conștiinței; termenul biologic adaptare se referă, probabil, mai degrabă la funcții generale sau de specie. Oricum, oricare dintre ei este potrivit ${ }^{9}$.

[Traducere de Francisc Gafton și Adina Chirilă]

\footnotetext{
${ }^{9}$ Deja am notat (ref. d. și f.) că Profesorul Lloyd Morgan și Profesorul H.F. Osborn au ajuns la concluzii similare cu a mea, asupra selecției organice. Nu știu dacă ei acceptă acest nume pentru 'factor', dar, așa cum l-am sugerat în prima ediție a cărții mele (apr., 1895) și l-am folosit mai devreme, îndrăznesc să sper că va fi acceptat de către biologi.
} 